\title{
Hope and Optimism: A Spinozist Perspective on COVID-19
}

\author{
Genevieve Lloyd $\mathbb{D}$
}

Received: 12 May 2020 / Accepted: 8 August 2020

(C) Journal of Bioethical Inquiry Pty Ltd. 2020

\begin{abstract}
This essay discusses hope and optimism with reference to current rhetoric around COVID-19. It draws on Spinoza to suggest that much of that rhetoric rests on questionable assumptions about the supremacy of human reason within Nature.
\end{abstract}

Keywords Hope Optimism - Spinoza $\cdot$ Reason COVID-19

Much of current rhetoric in response to the global impact of COVID-19 centres on a confident affirmation of collective human well-being, beyond the present crisis. We are encouraged to remember and to celebrate the endurance and resilience that have seen particular communities, and the human species in general, through so much in the past. That insistent optimism finds reinforcement in common metaphors of war-of resistance in the face of a deadly enemy - and of eventual victory.

The implicit message here is that the manifest effects of the pandemic should be seen as temporary glitches in an ongoing triumphal story, in which humanity fights back against hostile Nature. Such narratives are meant to communicate — and to instil- hope. However, they rest on a construal of hope in terms of assurance of future deliverance, whatever the temporary trauma or grief along the way. It is easy to be swept along by such rhetoric. The appeal to resilience in the face of adversity

\section{G. Lloyd $(\bowtie)$}

University of New South Wales, Sydney, Australia

e-mail: GenevieveLloyd@bigpond.com seems appropriate and necessary; and it is difficult to resist - or even to question - the evoking of hope. Yet, there are some grounds for unease in relation to the resolute expectation of future well-being.

In an essay published in The Monthly, the Australian writer and commentator Don Watson (2020) has offered an intriguing insight on the difference between hope and optimism in the context of the pandemic. Hope, he observes, is essential for human beings, but optimism is voluntary; and it can, in its assured confidence about the future, be deadly. I want here to explore that distinction by drawing on the thought of the seventeenth century Dutch philosopher, Benedict de Spinoza.

Underlying the current rhetoric of optimism are narratives of perfectibility and of progress, which were articulated later in the history of western philosophy. They draw on assumptions of the supremacy of human reason, construed as transcending "mere" Nature. Spinoza offers an alternative perspective, which can now be seen as an intellectual path not taken. His philosophy emphasizes the interdependence of humanity and the world in which it is shaped, and on which it leaves its own inexorable traces.

In the early eighteenth century there was a philosophical version of optimism, which left its mark on later developments in the imagining of assured progress of the human species towards perfection through exercise of distinctive capacities for rational thought. That "metaphysical optimism" rested on the notion of a benign providential order of things, in which apparent evil falls into place within the perfection of the whole. As Alexander Pope (1829) put it in his An Essay on Man, within 
that bigger picture, whatever is, is right. In a more philosophically nuanced version of the idea, later elaborated in Gottfried Leibniz's Theodicy, the actual world excludes the existence of other less perfect-less rationally ordered - possible worlds. Shorn of its philosophical niceties, this was the idea later pilloried by Voltaire (1759) in his famous satire Candide, in which the Leibnizian doctrine is mouthed by the fatuous tutor Pangloss, who sees actual perfection in the midst of every apparent disaster.

Spinoza's version of humanity's place in the whole of Nature also emphasized the broader context of human life. However, he developed that theme in a radically different way, rejecting all notion of purpose or design in the natural world. Rather than offering assurance of a world rationally ordered towards ultimate human wellbeing, reason is itself part of Nature-inserted into a totality of finite processes, which have no bearing on what may be "best" for human beings.

Spinoza thus offered a very different version of humanity's place in Nature from a more familiar one - strikingly articulated by his contemporary, Blaise Pascal. In his Pensées (1852), Pascal famously observed that - despite being like a fragile reed, liable to be destroyed by a vapour - human beings are superior to the might and power of the whole of Nature; for they are unique in being things that think. Pascal's exultation in the nobility of human thought resonates throughout later philosophy. It was explicit in the notion of the Sublime - the ancient aesthetic concept revived in the eighteenth century, largely through strands in the thought of Immanuel Kant. In his Critique of Judgement, Kant presented the sense of the Sublime as arising in reason's recognition of "the appropriate sublimity of the sphere of its own being, even above Nature" (Kant 1952[1790], 111-112).

Like other philosophers of his time - and many who came later-Spinoza celebrated the powers of human reason. Yet his affirmation of reason is framed by insistence on the doctrine for which he is most famous - and notorious: the treatment of minds and bodies alike as finite modes of a non-transcendent unique Substance, identified as God-or-Nature. An individual mind is for him not a free-standing intellectual substance but a modification of that one Substance, under one of its Attributes-Mind, or Thought.

In terms of more recent debates in the philosophy of mind, Spinoza is neither a "dualist" nor a "materialist." For him, minds and bodies are not reducible in either direction. Nor is a mind superior to - or nobler thanthe body, of which it is the idea. Minds and bodies have equal status as finite modes of Substance, under different Attributes-Mind or Thought, and material Extension. They are united, across that difference in Attributes, in a non-causal relation of ideas to their objects.

"The object of the idea constituting the human Mind is the Body or a certain mode of Extension which actually exists, and nothing else" (Spinoza 1985 [1677]; Kant 1952[1790], Part II, Proposition 13). Whether as mind or as body, a human being is inserted into - and hence vulnerable within - the totality of Nature. "The force by which a man perseveres in existing is limited, and infinitely surpassed by the power of external causes" (Spinoza 1985 [1677]; Kant 1952[1790], Part IV, Proposition 3).

At a superficial level, the observation that human beings are themselves part of the reality they know can seem commonplace: we know that we are not positioned outside the world like observing gods, viewing it from nowhere. Yet we do readily imagine human knowledge as a relation between a mind - complete unto itselfand a world of things external to it, including its own body. Spinoza challenges that way of thinking, demanding serious engagement with the ramifications of acknowledging that human minds are minds-in-world, understanding that world only from within it. For him, a mind's thinking processes reflect its immersion in the dynamic totality of the whole of Nature - vulnerable to rival forces and powers, as well as able to draw strength from those con- genial to its own persistence in existence. "We are acted on, insofar as we are a part of Nature, which cannot be conceived through itself, without the others" (Spinoza 1985[1677], Part IV, Proposition 2).

What does all this mean for hope? In Part III of his Ethics, Spinoza defines it in tandem with Fear. Hope is an inconstant Joy, associated with the thought of an uncertain future outcome. Fear is an inconstant Sadness, similarly associated with uncertainty about what lies in the future. Where no such uncertainty is felt, Hope is replaced by Confidence - an assured expectation, not unlike what we now call "optimism."

What is significant here is that Hope is seen as grounded in a more basic emotion-Joy, which Spinoza defines as the mind's transition out of passivity into greater activity. Hope is thus presented as a tremulous anticipation of Joy - in the midst of uncertainty. That connects it with something even more central in 
Spinoza's philosophy - the dynamic concept he calls conatus: the effort to persist in existence. A human mind, like all other finite things, has conatus as its essence; and for it, that essence resides in the effort to better understand its relations with other things within the totality of Nature. Its continued existence involves ongoing transitions into greater activity or passivityjoy or sorrow - under the impact of forces external to it.

In thus connecting Hope- through its associations with Joy — with the essence of the mind, Spinoza offers, not so much a reason for hope, as an insight into its preconditions. In Hope a mind is aware of the onward movement - the struggle to persist - of life itself. Thinking minds are thus for Spinoza integrated, for better or worse, into the totality of the powers of Nature. Humanity does not occupy any privileged place in a benignly ordered whole, shaped to ultimately accommodate its well-being.

The ramifications of Spinoza's perspective on human reason are developed in his political writings. In Chapter 16 of the Theological-Political Treatise (Spinoza 2001), he offers a startling image of human reason as a small speck, struggling to persist within the immensity of the whole of being. We may want the whole of Nature to be directed according to how we think, but in reality human reason is adapted only to its own workings as a tiny part of that whole.

It may seem an unhopeful picture of what can be expected for-or from-human reason, adrift in the immensity of Nature. Yet for Spinoza actively understanding the interdependence of finite things brings its own remedy for the negative passions associated with fear; for the activity of rational thinking is, by definition, itself an enactment of Joy.

Despite its initial strangeness, Spinoza's insistence that human reason is itself but a speck within the whole of Nature can seem strikingly prescient in the light of developments in contemporary physics and cosmology. Yet he remains largely an "outsider" in the history of western thought. His philosophy draws on ancient sources, which were taken up and developed also in the writings of other philosophers, whose thought is more "mainstream" for contemporary consciousness. He draws on Stoicism, on Epicureanism, on Aristotle, on Descartes. However, he also draws on less familiar sources-on Maimonides, Averroes, Avicennaimaginatively adapting and modifying them into his own distinctive system.
In their startling unfamiliarity, Spinoza's insights into humanity's place within Nature can open up possibilities for constructive re-thinking of what is at stake for human presence on a changing planet. Perhaps Spinozist hope might better sustain us, as we move into an uncertain future, than a more familiar state of optimism, grounded in illusory assumptions of human supremacy over "mere" Nature.

Thinking through with Spinoza what it is to be truly part of Nature would require re-thinking - intellectually, imaginatively, emotionally-a prevailing mindset which has shaped attitudes towards human presence in the world. He responded to what he saw as a false imagining of humanity as lodged in the world as if it were an autonomous, self-contained "kingdom within a kingdom," carved out within the whole of Nature.

Re-thinking that imagining would involve taking seriously human finitude and the vulnerability inherent in struggling for survival within rather than against the rest of Nature.

In the context of the current COVID-19 crisis, recognizing the dangerous limitations of that underlying mindset might well involve acknowledging points of connection - shared underlying conditions - between the pandemic and ongoing crises of climate change: the unthinking encroachment of human interests into previously "wild" Nature; the displacement of species from destroyed habitat; the mass movements of people from depleted environments.

On a Spinozist approach, human well-being depends on coming to an ever deeper understanding of humanity's interdependence with the rest of Nature. In the conclusion to his Ethics, he described that understanding as "excellent," though "difficult" and "rare." In our own times, it is a pressing challenge to try to engage in such re-thinking.

\section{References}

Kant, I. 1952 [1790]. The critique of judgement. Translated by J.C. Meredith. Oxford: Clarendon Press.

Pascal, B. 1852. Pensées [Thoughts]. Dezobry and E. Magdeleine. Pope, A. 1829. An essay on man: And other poems. Duke Street, Piccadilly.

Spinoza, B. de. 1985 [1677]. Ethics. In The collected works of Spinoza, Vol I. Edited and translated by E. Curley. Princeton: Princeton University Press.

Spinoza, B. de. 2001. Theological-political treatise. Hackett Publishing. 
Voltaire. 1759. Candide, ou l'optimisme. France: Cramer, MarcMichel Rey, Jean Nourse, Lambert.

Watson, D. 2020. What lessons will we learn from the virus? The Monthly, May. https://www.themonthly.com.au/issue/2020 /may/1588255200/don-watson/what-lessons-will-we-learnvirus\#mtr. Accessed August 5, 2020.
Publisher's note Springer Nature remains neutral with regard to jurisdictional claims in published maps and institutional affiliations. 